ACTA MYCOLOGICA

Vol. 39 (2): 123-138

2004

\title{
Arbuscular fungi and mycorrhizae in agricultural soils of the Western Pomerania II. Distribution of arbuscular fungi
}

\author{
ANNA IWANIUK and JANUSZ BEASZKOWSKI \\ Department of Plant Pathology, University of Agriculture \\ Slowackicgo 17, PL-71-434 Szczecin \\ jblaszkowski@agro.ar.szczecin.pl
}

Iwan iu k A., Błaszkowski J.: Arbuscular fungi and mycorrhizae in agricultural soils of the Western Ponerania. II. Distribution of arbuscular fungi. Acta Mycol. 39 (2): 123-138, 2004.

This part of the two-part paper of arbuscular mycorrhizal fungi (AMF) of the phylum Glomeromycota of agricultural soils of the Western Pomerania, north-western Poland, presents the distribution of 26 species of these fungi in both the sites considered in this study and cultivated soils of other regions of Poland and the world investigated previously. The fungi were isolated from both field-collected rhizosphere soil and root mixtures and trap cultures established from each field sample and seeded with three species of plant hosts. Among the fungal species characterized, 18 are of the genus Glomus, one each of the genera Archaeospora, Entrophospora and Paraglomus, and three and two of the genera Acaulospora and Scutellospora, respectively.

Key words: arbuscular fungi, agricultural soils, distribution, Western Pomerania, Poland

\section{INTRODUCTION}

This paper continues the presentation of arbuscular mycorrhizal fungi (AMF) of the phylum Glomeromycota found in agricultural soils of the Western Pomer-

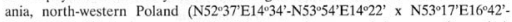
$\mathrm{N} 54^{\circ} 33^{\prime} \mathrm{E} 16^{\circ} 40^{\circ}$ ), in the years 1998-2000. In the first part of the paper (Iwaniuk and Błaszkowski 2004), the general occurrence of spores of AMF in both fieldcollected rhizosphere soil and root samples and trap cultures established from each field sample and seeded with three plant host species were described. The frequency of occurrence and the dominance of the arbuscular fungal species revealed, as well as the abundance of spores and the species richness of these fungi among roots of the plant families and species examined were also characterized. Additionally, the level of mycorrhizal colonization of selected plant species cultivated in the ficld and the correlations between soil chemical properties and the occurrence of spores and species of the AMF revealed were showed. Finally, the species composition of 
the AMF found by the authors of this paper and that revealed by B taszkowski (1993a) in the years 1985-1990 was compared.

The aim of this paper is to present the distribution of the arbuscular fungal species found in agricultural soils of the Western Pomerania (I w a n iuk and B taszkowski 2004) as well as in cultivated sites of other regions of both Poland and the world examined previously.

\section{MATERIALS AND METHODS}

The study area, its climatic conditions, the methods of collection of rhizosphere soil and root mixtures, establishment of trap and one-species cultures, as well as the methods of isolation and identification of the spores of AMF recovered were presented in the first part of this paper (Iwaniuk and Błaszkowski 2004). Additionally, the terminology of spore structure, the classification of AMF, as well as the statistical terms used here are as those characterized previously.

Color microphotographs of spores and mycorrhizae of the AM fungal species presented below can be viewed at the URL http://www.agro.ar.szczecin.pl/ $\sim$ jblaszkowski/.

\section{RESULTS}

The data of the origin of the arbuscular fungal species characterized below were presented in the first part of the paper (Iwaniuk and B aszkowski 2004). Briefly, the fungi were isolated from 162 mixtures of rhizosphere soil and roots coming from under 10 plant species cultivated in 109 localities of the Western Pomerania in the years 1998-2000. Most soil and root samples represented the family Poaceae (121 samples). The plant species most frequently sampled was Triticum aestivum $\mathbf{L}$.

During the three-year study, a total of 25707 spores of AMF were isolated, of which 7453 came from field-collected samples and 18254 from trap cultures. The spores represented seven of the eight existing genera of the phylum Glomeromycota (Schüßler et al. 2001). Among the spores isolated, 26 species were identified, including 18 species of the genus Glomus, one each of the genera Archaeospora, Entrophospora and Paraglomus, and three and two of the genera Acaulospora and Scutellospora, respectively.

\section{Distribution of arbuscular mycorrhizal fungi in agricultural soils of the Western Pomerania}

The data of records made in other regions of Poland and the world regard only collections coming from cultivated sites.

Abbreviations:

$\mathrm{n}$ - number of soil and root samples coming from under plants growing in the field in which a given fungal species was found,

$\mathrm{nPl}$ - number of trap cuitures with spores of a given fungal species, when the plant host was Plantago lanceolata,

$\mathrm{nSv}$ - number of trap cultures with spores of a given fungal species, when the plant host was Sorgram valgare,

$\mathrm{nZm}$ - number of trap cultures with spores of a given fungal species, when the plant host was Zea mays. 
The numbers that follow are those of sites presented in Table 1 and Fig. 1, as well as those mentioned in the list of sites showed in Table 2 (I waniuk and Błaszkowski 2004).

Acaulospora capsicula Błaszk.

$\mathrm{n}=0 ; \mathrm{nPl}=0 ; \mathrm{nSv}=1 ; \mathrm{nZn}=0: 119 \mathrm{~Sv}$.

Spores of Ac. capsicula were found only in one trap culture with the rhizosphere soil and roots of T. aestivum cultivated in Wardyń.

General distribution. Blaszkowski (1993a) revealed Ac, capsicula in five cultivated sites of Poland. Acaulospora colossica Schultz et al. described from spores found in the USA (Schultz et al. 1999) probably is synonymous with Ac. capsicula.

Acaulospora paulinae Błaszk.

$\mathrm{n}=4 ; \mathrm{nPl}=0 ; \mathrm{nSv}=1: 1,1 \mathrm{~Sv}, 5,136,140$.

As the results of isolation of spores from both the field and trap culture samples showed, in the cultivated sites of the Western Pomcrania, Ac. paulinae occurred infrequently and was hosted by Beta vulgare, Brassica oleracea, Secale cereale and $T$. aestivum.

General distribution. Acaulospora paulinae has been described from spores isolated from under Lupimus luteus L. (Błaszkowski 1988). Koske et al. (1997) encountered this fungus associated with Agrostis canina Huds., $A$. palustris L., and Poa annua L., perennial turf species of golf greens of Rhode Island, USA.

Remarks. Acaulospora paulinae probably is widely distributed both in Poland and the other regions of the world, although it occurs rather infrequently.

\section{Acaulospora thomii Błaszk.}

$\mathrm{n}=1 ; \mathrm{nPl}=0 ; \mathrm{nSv}=1 ; 785 \mathrm{v}, 136$

Acaulospora thomii occurred only in two cultivated sites of the Western Pomerania where the plant host grown was $S$. cereale.

General distribution. Acaulospora thomii has been described based on spores isolated from among roots of $T$. aestivum growing in Bolesławiec (Błaszkowski 1988). This paper is the second report of the occurrence of this fungus in Poland.

Acaulospora thomii has recently been revealed in Switzerland (Dr. Fritz Oehl, Botanisches Institut, Universität Basel, pers. inf.).

\section{Archaeospora trappei Ames et Linderman}

$\mathrm{n}=0 ; \mathrm{nPl}=4 ; \mathrm{nSv}=4 ; \mathrm{nZn}=6: 25 \mathrm{Pl}, 25 \mathrm{Zn}, 28 \mathrm{~Sv}, 29 \mathrm{Pl}, 30 \mathrm{Zn}, 31 \mathrm{Zn}, 43 \mathrm{~Sv}, 55 \mathrm{Zn}, 57 \mathrm{Zn}, 59 \mathrm{Pl}, 84 \mathrm{Zn}, 135 \mathrm{~Sv}$, $136 \mathrm{Pl}, 160 \mathrm{~Sv}$.

In the studies presented here, Arch. trappei was revealed only in trap cultures.

General distribution. Archaeospora trappei has been described from spores isolated from trap cultures with the rhizosphere soil and roots collected from under Lilium longiflorum Thunb. growing in California and Oregon (A mes and Linder- 
man 1976). Additionally, this fungus has been found in cultivated soils of Florida (Schenck and Smith 1981; Schenck and Kinloch 1980), Kansas (Hetrick and Bloom 1983), Israel (Haas and Menge 1990), Australia (Abbott 1982), and among roots of different plants cultivated in Brazil and Japan (Morton and Redecker 2001).

Archaeospora trappei probably commonly occurs in both Poland and the world as the results of studies of trap cultures representing different cultivated and uncultivated plants growing in different regions of Europe (B a aszkowski, pers. observ.).

Remarks. The lack of findings of Arch. trappei in the field-collected samples may have resulted from either the omission of spores of this fungus or their absence at the time of collection of soil and root samples due to decomposition of spores by soil microorganisms or seasonal sporulation of the fungus. Archaeospora trappei produces small and colourless spores with one wall consisting of thin and delicate layers. Many soil microorganisms have been identified to parasite spores of AMF (Lee and Koske 1994). The seasonality of sporulation has been found in many species of AMF (e. g., Ge m ma et al. 1989).

\section{Entrophospora infrequens (Hall) Ames et Schneider}

$\mathrm{n}=3: 151 \mathrm{PI}, 136 \mathrm{~S} v, 148 \mathrm{Zn}$.

General distribution. Entrophospora infrequens has originally been described as Gl. infrequens Hall from spores discovered in New Zealand (Hall 1977). However, the description was incomplete. Following the finding of specimens representing all developmental stages of this fungus among roots of Opium graveolens L. cultivated in California, Ames and Schneider (1979) transferred Gl. infrequens to a newly erected genus, Entrophospora Ames et Schneider. Entrophospora infrequens has subsequently been found in many other cultivated sites of the USA (Hetrick and Bloom 1983; Pfleger and Stewart 1989; Schenck and Smith 1982; Stahl and Christensen 1982), Switzerland (Jansa et al. 2002), Finland (Vestberg 1995), and Australia (Hall and Abbott 1984). Błaszkowski (1993a) revealed $E$. infrequens only in four cultivated sites of Poland.

Glomus aggregatum Schenck et Smith emend. Koske

$\mathrm{n}=3 ; \mathrm{nPl}=1 ; \mathrm{nSv}=0 ; \mathrm{nZn}=0: 9,11,44,149 \mathrm{Pl}$.

The studies of the authors of this paper showed that Gl. aggregatum co-occurred with $B e$. vulgaris, $F$. vesca, and T. aestivum growing in three localities of the Western Pomerania.

General distribution. Glomus aggregatum has originally been described based on spores recovered from among roots of Citrus sinensis x Ponicirus trifoliata cultivated in Florida (Schenck and Smith 1982). Błaszkowski (1993a) found spores of this fungus in 15 cultivated sites of Poland.

Remarks. Glomus aggregatum probably has a worldwide distribution, although Koske (1985) and Blaszkowski (1991) suggest this fungus to prefer sandy soils, especially sand dunes.

Glomus aggregatum distinguishes the formation of loose aggregates and extensive extraradical hyphae binding sand grains into aggregates. Hence, Gl. aggregatum 
is considered to play a significant role in improving soil structure and counteracting their erosion (Błaszkowski 1991; Koske and Halvorson 1981).

\section{Glomus caledonium Trappe et Gerd.}

$\mathrm{n}=34: \mathrm{nPl}=48 ; \mathrm{nSv}=42 ; \mathrm{nZn}=65: 1,1 \mathrm{~Sv}, 1 \mathrm{Zn}, 2 \mathrm{Pl}, 2 \mathrm{~Sv}, 3 \mathrm{Pl}, 3 \mathrm{~Sv}, 4,4 \mathrm{~Sv}, 4 \mathrm{Zn}, 5 \mathrm{~Sv}, 5 \mathrm{Zn}, 7 \mathrm{Pl}, 7 \mathrm{Zn}, 8 \mathrm{~Sv}$, $8 \mathrm{Zn}, 9 \mathrm{Zn}, 10,12 \mathrm{Pl}, 13 \mathrm{Pl}, 14 \mathrm{~Sv}, 17 \mathrm{Pl}, 17 \mathrm{~Sv}, 17 \mathrm{Zn}, 19 \mathrm{~Sv}, 20,20 \mathrm{Pl}, 22 \mathrm{~Sv}, 24 \mathrm{Pl}, 24 \mathrm{~Sv}, 24 \mathrm{Zn}, 25 \mathrm{~Sv}, 26 \mathrm{Pl}, 26 \mathrm{~Sv}$, $26 \mathrm{Zn}, 27 \mathrm{~Sv}, 27 \mathrm{Zn}, 29,32,33 \mathrm{Pl}, 34,34 \mathrm{~Sv}, 34 \mathrm{Zn}, 35 \mathrm{Pl}, 35 \mathrm{Zn}, 36 \mathrm{Pl}, 36 \mathrm{~Sv}, 36 \mathrm{Zn}, 37 \mathrm{Pl}, 41,41 \mathrm{Zn}, 43 \mathrm{Pl}, 43 \mathrm{~Sv}$, $44,44 \mathrm{Pl}, 44 \mathrm{~Sv}, 45 \mathrm{Pl}, 46,46 \mathrm{Pl}, 46 \mathrm{~Sv}, 46 \mathrm{Zn}, 47 \mathrm{Pl}, 48,48 \mathrm{Pl}, 48 \mathrm{~Sv}, 48 \mathrm{Zn}, 49,49 \mathrm{Zn}, 51 \mathrm{~Sv}, 52 \mathrm{Pl}, 52 \mathrm{~Sv}, 52 \mathrm{Zn}$, $53 \mathrm{Zn}, 54 \mathrm{Pl}, 54 \mathrm{Zn}, 55 \mathrm{Pl}, 56 \mathrm{Zn}, 57 \mathrm{Pl}, 60 \mathrm{Zn}, 61,61 \mathrm{Zn}, 62,62 \mathrm{~Sv}, 64,64 \mathrm{~Sv}, 66 \mathrm{Zn}, 68 \mathrm{Pl}, 68 \mathrm{~Sv}, 69 \mathrm{Zn}, 72 \mathrm{Zn}$, $74 \mathrm{Zn}, 77,78,78 \mathrm{Pl}, 79 \mathrm{PI}, 79 \mathrm{Zn}, 83 \mathrm{Zn}, 86 \mathrm{Zn}, 89 \mathrm{Zn}, 90,90 \mathrm{Pl}, 90 \mathrm{~Sv}, 92,92 \mathrm{~Sv}, 93,93 \mathrm{Zn}, 96,96 \mathrm{Zn}, 97,98 \mathrm{Zn}$, $99 \mathrm{~Sv}, 100 \mathrm{Zn}, 101,102 \mathrm{Zn}, 106,106 \mathrm{~Sv}, 107,108 \mathrm{Zn}, 112 \mathrm{Pl}, 113,113 \mathrm{Pl}, 115 \mathrm{~Sv}, 115 \mathrm{Zn}, 117,117 \mathrm{Zn}, 118 \mathrm{Pl}$, $120 \mathrm{Zn}, 121,121 \mathrm{Zn}, 122,122 \mathrm{Zn}, 125 \mathrm{Pl}, 126 \mathrm{Pl}, 127 \mathrm{Pl}, 127 \mathrm{Zn}, 128,128 \mathrm{~Sv}, 129 \mathrm{Pl}, 129 \mathrm{Zn}, 130 \mathrm{Pl}, 130 \mathrm{~Sv}$, $130 \mathrm{Zn}, 131 \mathrm{Pl}, 132 \mathrm{PI}, 133 \mathrm{PI}, 133 \mathrm{Zn}, 134 \mathrm{~Sv}, 135 \mathrm{Pl}, 135 \mathrm{Zn}, 136 \mathrm{~Sv}, 137 \mathrm{PI}, 137 \mathrm{Zn}, 138 \mathrm{Zn}, 142 \mathrm{Pl}, 143 \mathrm{Zn}$, $144 \mathrm{~Sv}, 144 \mathrm{Zn}, 145 \mathrm{~Sv}, 145 \mathrm{Zn}, 146 \mathrm{Zn}, 147 \mathrm{Pl}, 147 \mathrm{Zn}, 148,148 \mathrm{Pl}, 148 \mathrm{~Sv}, 148 \mathrm{Zn}, 149 \mathrm{Zn}, 150 \mathrm{Pl}, 150 \mathrm{Zn}$, $152 \mathrm{Zn}, 1535 \mathrm{v}, 154,154 \mathrm{PI}, 154 \mathrm{Zn}, 155 \mathrm{PI}, 155 \mathrm{Zn}, 156,156 \mathrm{~Sv}, 156 \mathrm{Zn}, 157 \mathrm{Zn}, 158 \mathrm{PI}, 159,159 \mathrm{PI}, 159 \mathrm{Zn}$. $160 \mathrm{Pl}, 160 \mathrm{Zn}, 161 \mathrm{Pl}, 162 \mathrm{Pl}, 162 \mathrm{Zn}$.

Glomus caledonium was the forth most frequently found species of AMF in cultivated soils of the Western Pomerania examined in this study. The fungus was associated with all the plant species considered. Spores of this fungus were found in both poor sandy and fertile humus soils.

General distribution. Glomus caledonium is widely distributed in the world. This fungus has originally been described from spores coming from a meadow soil located in Scotland (Nicolson and Gerdemann 1968). Other reports of its findings in cultivated soils are, e. g., those from the USA (Gerdem an $n$ and Trappe 1974; Miller et al. 1985; Pfleger et al. 1989), Germany (Land and Schönbeck 1991), Finland (Vestberg 1995), New Zealand and Australia (Hall 1975; Hall and Abbott 1984), India (Selvaraj and Subram anian 1987), and Taiwan (Wu and Chen 1986).

Blaszkowski (1993a) found Gl. caledonium in 59 of the 173 soil samples collected from under plants cultivated in different regions of Poland where it ranked seventh in respect of the frequency of occurrence.

\section{Glomus claroideum Schenck ct Smith}

$\mathrm{n}=19 ; \mathrm{nPl}=54 ; \mathrm{nSv}=47 ; \mathrm{nZn}=79: 1,1 \mathrm{Pl}, 1 \mathrm{Zn}, 3 \mathrm{PI}, 4 \mathrm{~Sv}, 4 \mathrm{Zn}, 5 \mathrm{Pl}, 5 \mathrm{~Sv}, 5 \mathrm{Zn}, 6 \mathrm{Pl}, 6 \mathrm{~Sv}, 6 \mathrm{Zn}, 7,7 \mathrm{Pl}, 7 \mathrm{Zn}, 8 \mathrm{Pl}$, $8 \mathrm{~Sv}, 9 \mathrm{Pl}, 9 \mathrm{~Sv}, 9 \mathrm{Zn}, 10,10 \mathrm{Zn}, 11 \mathrm{Pl}, 11 \mathrm{~Sv}, 12 \mathrm{Pl}, 13 \mathrm{Pl}, 12 \mathrm{Zn}, 13 \mathrm{Zn}, 14 \mathrm{Pl}, 14 \mathrm{~Sv}, 14 \mathrm{Zn}, 15 \mathrm{Pl}, 15 \mathrm{Zn}, 17 \mathrm{PI}, 17 \mathrm{~Sv}$, $17 \mathrm{Zn}, 18 \mathrm{Pl}, 18 \mathrm{~Sv}, 18 \mathrm{Zn}, 20 \mathrm{~Sv}, 20 \mathrm{Zn}, 215 \mathrm{v}, 22 \mathrm{Pl}, 23 \mathrm{Pl}, 23 \mathrm{Zn}, 24 \mathrm{Pl}, 24 \mathrm{~Sv}, 24 \mathrm{Zn}, 25 \mathrm{Pl}, 25 \mathrm{~Sv}, 25 \mathrm{Zn}, 26 \mathrm{Pl}$ $26 \mathrm{~Sv}, 26 \mathrm{Zn}, 27 \mathrm{PI}, 27 \mathrm{~Sv}, 27 \mathrm{Zn}, 28 \mathrm{Zn}$, 30Sv, 30Zn, 31Pl, 31Sv, 32PI, 32Zn, 33PI, 34PI, 34Sv, 34Zn, 35PI. $35 \mathrm{~Sv}, 35 \mathrm{Zn}, 36 \mathrm{Pl}, 36 \mathrm{~Sv}, 36 \mathrm{Zn}, 37 \mathrm{Pl}, 37 \mathrm{~Sv}, 40 \mathrm{Pl}, 42 \mathrm{~Sv}, 42 \mathrm{Zn}, 43 \mathrm{~Sv}, 43 \mathrm{Zn}, 44 \mathrm{~Sv}, 45 \mathrm{~Sv}, 46 \mathrm{Pl}, 46 \mathrm{~Sv}, 46 \mathrm{Zn}$. $47 \mathrm{Pl}, 47 \mathrm{~Sv}, 47 \mathrm{Zn}, 48,48 \mathrm{Pl}, 48 \mathrm{~Sv}, 48 \mathrm{Zn}, 50 \mathrm{Pl}, 50 \mathrm{Zn}, 51 \mathrm{Pl}, 52 \mathrm{Pl}, 53 \mathrm{Pl}, 53 \mathrm{~Sv}, 53 \mathrm{Zn}, 54 \mathrm{Pl}, 54 \mathrm{~Sv}, 54 \mathrm{Zn}, 55 \mathrm{~Sv}$ $58 \mathrm{~Sv}, 58 \mathrm{Zn}, 60 \mathrm{Pl}, 60 \mathrm{Zn}, 62,62 \mathrm{Zn}, 63,63 \mathrm{Pl}, 63 \mathrm{~Sv}, 63 \mathrm{Zn}, 66 \mathrm{~Sv}, 67 \mathrm{Zn}, 69 \mathrm{Zn}, 72,73,74,75 \mathrm{Zn}, 76,77,79 \mathrm{~Sv}$ $81 \mathrm{Zn}, 86,86 \mathrm{Zn}, 87 \mathrm{Zn}, 89 \mathrm{Pl}, 89 \mathrm{Zn}, 91 \mathrm{Pl}, 91 \mathrm{Zn}, 93,94,94 \mathrm{Zn}, 95 \mathrm{Zn}, 98 \mathrm{Zn}, 99 \mathrm{~Sv}, 101,102 \mathrm{Zn}, 103 \mathrm{Zn}, 105 \mathrm{Pl}$ $105 \mathrm{Zn}, 109,109 \mathrm{Pl}, 109 \mathrm{~Sv}, 109 \mathrm{Zn}, 112 \mathrm{~Sv}, 112 \mathrm{Zn}, 114 \mathrm{PI}, 116 \mathrm{Zn}, 118 \mathrm{Zn}, 121 \mathrm{Zn}, 122 \mathrm{PI}, 122 \mathrm{Zn}, 123,123 \mathrm{PI}$ $123 \mathrm{Zn}, 124 \mathrm{~Sv}, 124 \mathrm{Zn}, 125 \mathrm{~Sv}, 125 \mathrm{Zn}, 128 \mathrm{PI}, 129 \mathrm{PI}, 129 \mathrm{Zn}, 130 \mathrm{Pl}, 130 \mathrm{~Sv}, 130 \mathrm{Zn}, 131 \mathrm{Zn}, 132 \mathrm{Zn}, 135 \mathrm{PI}$ $138 \mathrm{Zn}, 139,139 \mathrm{~Sv}, 140 \mathrm{PI}, 141 \mathrm{Zn}, 144 \mathrm{Zn}, 145 \mathrm{~Sv}, 145 \mathrm{Zn}, 146 \mathrm{Zn}, 147 \mathrm{Zn}, 149 \mathrm{Pl}, 149 \mathrm{~Sv}, 149 \mathrm{Zn}, 150 \mathrm{Zn}$ $151 \mathrm{~Sv}, 151 \mathrm{Zn}, 152 \mathrm{Pt}, 152 \mathrm{Zn}, 154 \mathrm{PL}, 154 \mathrm{~Sv}, 154 \mathrm{Zn}, 155 \mathrm{Zn}, 157 \mathrm{Zn}, 158 \mathrm{Zn}, 159,159 \mathrm{Pl}$.

The studies presented here showed that Gl claroideum was the third most frequently occurring species in cultivated soils of the Western Pomerania. When spores recovered from both field samples and trap cultures were considered, this fungus 
was the first among cudominants. Glomus claroideum co-occurred with all the plant species examined.

General distribution. Glomus claroideum has originally been described based on spores coming from under Glycine max (L.) Merr. cultivated in Florida (Schenck and Smith 1982). According to Walker and Vestberg (1998), this fungus is widely distributed in the northern Europe, whereas only two reports come from the southern hemisphere.

Remarks. Glomus claroideum is a species difficult to identify based on spores isolated from the field. The spores usually lack two outermost layers of their wall, which are exceptionally short-lived. Additionally, the innermost spore wall layer of this species usually tightly adheres to the penultimate laminate layer and, thereby, may be indistinguishable. Glomus claroideum has not earlier been found in cultivated soils of Poland. Using methods of molecular biology, Tu rn a u et al. (2001) revealed Gl. claroideum in roots of $F$, vesca growing in highly $\mathrm{Zn}$-contaminated heaps located near Chrzanów, southern Poland.

\section{Glomus clarum Nicolson et Schenck}

$\mathrm{n}=1: 24 \mathrm{Pl}$.

Glomus clarum was revealed in only one trap culture representing $Z$. mays cultivated in Stary Chrapów.

General distribution. Glomus clarum has been described from spores isolated from the rhizosphere soil of Paspalum notatum Flugge cultivated in Florida (Nicolson and Schenck 1979).

This fungus also co-occurred with other plants cultivated in the USA (Hetrick and Bloom 1983; Miller et al. 1985; Schenck and Kinloch 1980), and South America (Schenck et al. 1984).

This paper is the first report of the occurrence of GL clarum in cultivated soils of Poland. In Poland, this fungus has earlier been found in maritime dunes (Błaszkowski 1994b) and inland dunes of the Bledowska Desert (Blaszkowski et al. 2002).

\section{Glomus constrictum Trappe}

$\mathrm{n}=43 ; \mathrm{nPl}=35 \mathrm{~Sv} ; \mathrm{nSv}=29 ; \mathrm{nZn}=26: 1 \mathrm{Pl}, 1 \mathrm{Zn}, 25 \mathrm{v}, 4,5,5 \mathrm{~Sv}, 7 \mathrm{Zn}, 15 \mathrm{Pl}, 16 \mathrm{PI}, 21 \mathrm{Pl}, 22,26 \mathrm{~Sv}, 27 \mathrm{Pl}, 29$, $29 \mathrm{~Sv}, 32,32 \mathrm{Pl}, 32 \mathrm{Zn}, 33 \mathrm{Pl}, 33 \mathrm{~Sv}, 36 \mathrm{Zn}, 37 \mathrm{Pl}, 37 \mathrm{~Sv}, 38 \mathrm{~Sv}, 39 \mathrm{Pl}, 41,42 \mathrm{Zn}, 43,46 \mathrm{~Sv}, 48 \mathrm{Pl}, 49 \mathrm{Pl}, 58,61,61 \mathrm{Pl}$, $61 \mathrm{Zn}, 64 \mathrm{~Sv}, 64 \mathrm{Zn}, 65 \mathrm{Pl}, 66 \mathrm{~Sv}, 67,67 \mathrm{Pl}, 67 \mathrm{~Sv}, 70 \mathrm{Pl}, 70 \mathrm{Zn}, 71,71 \mathrm{Pl}, 71 \mathrm{Zn}, 72,72 \mathrm{Pl}, 72 \mathrm{Zn}, 73 \mathrm{Pl}, 74 \mathrm{Zn}, 76 \mathrm{~Sv}$, $76 \mathrm{Zn}, 77 \mathrm{Zn}, 78 \mathrm{~Sv}, 79,79 \mathrm{~Sv}, 79 \mathrm{Zn}, 80,80 \mathrm{~Sv}, 81,82,83,83 \mathrm{PI}, 84 \mathrm{Pl}, 86,86 \mathrm{~Sv}, 88,88 \mathrm{~Sv}, 89 \mathrm{Pl}, 90,90 \mathrm{Zn}, 93$, 93Pl, 93Sv, 98, 98S $v, 99,101,102 \mathrm{Zn}, 103,104,106,107,107 \mathrm{~Sv}, 107 \mathrm{Zn}, 108 \mathrm{Pl}, 109,109 \mathrm{~Sv}, 109 \mathrm{Zn}, 110,111$. $111 \mathrm{Zn}, 113 \mathrm{PI}, 114,114 \mathrm{~Sv}, 117 \mathrm{Zn}, 118,118 \mathrm{PI}, 120,120 \mathrm{Zn}, 122,122 \mathrm{~Sv}, 124,124 \mathrm{Pl}, 124 \mathrm{~Sv}, 124 \mathrm{Zn}, 125 \mathrm{Zn}$, $127 \mathrm{Pl}, 127 \mathrm{Zn}, 128 \mathrm{Pl}, 129,130,130 \mathrm{Pl}, 131,133 \mathrm{Pl}, 134 \mathrm{Zn}, 136 \mathrm{~Sv}, 137,139 \mathrm{~Sv}, 141 \mathrm{Pl}, 144 \mathrm{Pl}, 148 \mathrm{Zn}, 149,152$, $152 \mathrm{~Sv}, 155 \mathrm{PI}, 156 \mathrm{~Sv}, 157 \mathrm{Pl}, 158 \mathrm{PI}, 162 \mathrm{~Sv}$.

Glomus constrictum occurred in almost $27 \%$ rhizosphere soil samples of the cultivated plants in the Western Pomerania and was more frequently found in field-collected samples than in trap cultures. This fungus was associated with all the plant species considered.

General distribution. The type of Gl constrictum has been described based on spores isolated from under Cocos nucifera L grown in Veracruz, Mexico (Trappe 
1977). The fungus has also occurred in cultivated soils of, e. g., California (Menge et al. 1978; Trappe 1977), Florida (Nemec et al. 1981), Kansas (Hetrick and Bloom 1983), Canada (Dalpé et al. 1986), and India (Suloch ma and Monoharachary 1989).

In Błaszkowski's (1993a) studies, Gl. constrictum was the third fungus in respect of the frequency of occurrence in cultivated soils of Poland.

\section{Glomus deserticola Trappe, Bloss et Menge}

$\mathrm{n}=124 ; \mathrm{nPl}=78 ; \mathrm{nSv}=77 ; \mathrm{nZn}=66: 1,2,3,3 \mathrm{Zn}, 4,5,6,6 \mathrm{~Sv}, 6 \mathrm{Zn}, 7,8,8 \mathrm{Pl}, 8 \mathrm{~Sv}, 8 \mathrm{Zn}, 9,10,11,12,12 \mathrm{Pl}$, $12 \mathrm{Zn}, 15,16,17,19,19 \mathrm{Pl}, 19 \mathrm{~Sv}, 21,22,23,25,26,27,28,29,29 \mathrm{Zn}, 30,30 \mathrm{Zn}, 31,31 \mathrm{Pl}, 31 \mathrm{~Sv}, 31 \mathrm{Zn}, 32,32 \mathrm{P}$, $32 \mathrm{~Sv}, 32 \mathrm{Zn}, 33,33 \mathrm{Zn}, 34,35,36,37,37 \mathrm{~Sv}, 38,38 \mathrm{Pl}, 39,41,42,43,44,44 \mathrm{Pl}, 44 \mathrm{~Sv}, 45,45 \mathrm{Pl}, 45 \mathrm{~Sv}, 45 \mathrm{Zn}, 46$, $47,49,49 \mathrm{Pl}, 50,50 \mathrm{Pl}, 50 \mathrm{~Sv}, 51,51 \mathrm{~Sv}, 51 \mathrm{Zn}, 52,55,55 \mathrm{Pl}, 55 \mathrm{Zn}, 56,58,59,60,61,61 \mathrm{Pl}, 63,63 \mathrm{~Sv}, 64,64 \mathrm{Pl}$, $64 \mathrm{Zn}, 65 \mathrm{Pl}, 65 \mathrm{Zn}, 66,66 \mathrm{Pl}, 68 \mathrm{Pl}, 68 \mathrm{Zn}, 69,69 \mathrm{~Sv}, 70,70 \mathrm{Pl}, 70 \mathrm{Zn}, 71 \mathrm{Pl}, 71 \mathrm{~Sv}, 71 \mathrm{Zn}, 72,72 \mathrm{~Sv}, 73 \mathrm{Zn}, 74$, 74PI, 74Sv, 74Zn, 75Pl, 75Sv, 76, 76Sv, 76 Zn, 77Sv, 77Zn, 78, 78PI, 80, 80PI, 80Zn, 81 Zn, 83, 83Pl, 83Sv, $83 \mathrm{Zn}, 84,84 \mathrm{Pl}, 84 \mathrm{~Sv}, 84 \mathrm{Zn}, 85 \mathrm{Pl}, 85 \mathrm{~Sv}, 85 \mathrm{Zn}, 865 \mathrm{v}, 86 \mathrm{Zn}, 87,87 \mathrm{Pl}, 87 \mathrm{~Sv}, 87 \mathrm{Zn}, 88,88 \mathrm{Pl}, 88 \mathrm{~Sv}, 88 \mathrm{Zn}, 89$, $89 \mathrm{~Sv}, 89 \mathrm{Zn}, 90,90 \mathrm{Pl}, 90 \mathrm{~Sv}, 90 \mathrm{Zn}, 91,91 \mathrm{PL}, 91 \mathrm{~Sv}, 91 \mathrm{Zn}, 92 \mathrm{Zn}, 93,93 \mathrm{~Sv}, 94,94 \mathrm{Pl}, 94 \mathrm{~Sv}, 94 \mathrm{Zn}, 95 \mathrm{Pl}, 95 \mathrm{~Sv}$, $95 \mathrm{Zn}, 97 \mathrm{~Sv}, 98 \mathrm{~Sv}, 99 \mathrm{~Sv}, 102 \mathrm{Zn}, 103,104 \mathrm{Pl}, 104 \mathrm{~Sv}, 104 \mathrm{Zn}, 105,105 \mathrm{PI}, 106,106 \mathrm{Pl}, 106 \mathrm{~Sv}, 107,107 \mathrm{PI}, 107 \mathrm{~Sv}$, $108,108 \mathrm{PI}, 108 \mathrm{~Sv}, 108 \mathrm{Zn}, 109,109 \mathrm{PI}, 110,110 \mathrm{Pl}, 110 \mathrm{~Sv}, 110 \mathrm{Zn}, 111,111 \mathrm{PI}, 111 \mathrm{~Sv}, 111 \mathrm{Zn}, 112,112 \mathrm{Pl}$, $112 \mathrm{~Sv}, 112 \mathrm{Zn}, 113,113 \mathrm{PI}, 113 \mathrm{~S} v, 113 \mathrm{Zn}, 114,114 \mathrm{PI}, 114 \mathrm{~Sv}, 114 \mathrm{Zn}, 115,115 \mathrm{Pl}, 115 \mathrm{~Sv}, 116,116 \mathrm{Pl}, 117 \mathrm{Pl}$, $118,118 \mathrm{Pl}, 118 \mathrm{~Sv}, 118 \mathrm{Zn}, 119,119 \mathrm{Pl}, 119 \mathrm{~Sv}, 119 \mathrm{Zn}, 120,120 \mathrm{~Sv}, 120 \mathrm{Zn}, 121,121 \mathrm{Pl}, 121 \mathrm{~Sv}, 122,122 \mathrm{Pl}$, $122 \mathrm{~Sv}, 122 \mathrm{Zn}, 123,123 \mathrm{Pl}, 123 \mathrm{~Sv}, 124,124 \mathrm{PI}, 124 \mathrm{Zn}, 125,125 \mathrm{Pl}, 125 \mathrm{~Sv}, 125 \mathrm{Zn}, 126,126 \mathrm{Pl}, 126 \mathrm{~Sv}, 126 \mathrm{Zn}$, $127,127 \mathrm{Pl}, 127 \mathrm{~Sv}, 128,128 \mathrm{~Sv}, 129 \mathrm{Pl}, 129 \mathrm{~Sv}, 130,131,132 \mathrm{Zn}, 133,133 \mathrm{~Sv}, 134,134 \mathrm{Pl}, 134 \mathrm{~Sv}, 134 \mathrm{Zn}, 135$, $135 \mathrm{Pl}, 135 \mathrm{~Sv}, 136,136 \mathrm{~Sv}, 137 \mathrm{Zn}, 138,138 \mathrm{Pl}, 138 \mathrm{~Sv}, 138 \mathrm{Zn}, 139,139 \mathrm{PI}, 140,140 \mathrm{PI}, 140 \mathrm{~Sv}, 140 \mathrm{Zn}, 141$, $141 \mathrm{Pl}, 141 \mathrm{~Sv}, 142,142 \mathrm{Pl}, 142 \mathrm{~Sv}, 142 \mathrm{Zn}, 143,143 \mathrm{PI}, 143 \mathrm{Zn}, 144,144 \mathrm{Pl}, 145,145 \mathrm{Pl}, 145 \mathrm{Zn}, 146,146 \mathrm{Pl}$. $146 \mathrm{~Sv}, 147,147 \mathrm{Pl}, 147 \mathrm{Zn}, 148 \mathrm{Pl}, 1485 \mathrm{v}, 149,150,150 \mathrm{Pl}, 150 \mathrm{~Sv}, 151,151 \mathrm{Pl}, 151 \mathrm{~Sv}, 152,152 \mathrm{Pl}, 152 \mathrm{~Sv}, 153$, $1535 \mathrm{v}, 153 \mathrm{Zn}, 154,154 \mathrm{Pl}, 154 \mathrm{~Sv}, 154 \mathrm{Zn}, 155,155 \mathrm{Pl}, 155 \mathrm{~Sv}, 155 \mathrm{Zn}, 156,156 \mathrm{Pl}, 156 \mathrm{~Sv}, 156 \mathrm{Zn}, 157,157 \mathrm{Pl}$, $157 \mathrm{~Sv}, 157 \mathrm{Zn}, 158,158 \mathrm{PI}, 158 \mathrm{~Sv}, 159,159 \mathrm{PI}, 159 \mathrm{~Sv}, 159 \mathrm{Zn}, 160,160 \mathrm{PI}, 160 \mathrm{~Sv}, 161,161 \mathrm{~Sv}, 161 \mathrm{Zn}, 162$.

Glomus deserticola was the species of AMF most frequently found in cultivated soils of the Western Pomerania. The fungus was associated with all the plant species examined.

General distribution. Glomus deserticola has been described using spores recovered from different plant species colonizing the deserts in California, Arizona, and Texas (Trappe et al. 1984). There is lack of information of the occurrence of this fungus in cultivated soils located outside Poland. In B 1aszkowski's (1993a) studies, Gl. deserticola was the second species in respect of the frequency of occurrence in cultivated soils of Poland.

\section{Glomus dominikii Błaszk.}

$\mathrm{n}=49 ; \mathrm{nPl}=35 ; \mathrm{nSv}=34 ; \mathrm{nZn}=31: 32,32 \mathrm{~Sv}, 44,55 \mathrm{Zn}, 56,62,62 \mathrm{PI}, 62 \mathrm{~Sv}, 62 \mathrm{Zn}, 63,67,68,68 \mathrm{Pl}, 68 \mathrm{~Sv}$, $68 \mathrm{Zn}, 70 \mathrm{Zn}, 71,72 \mathrm{Zn}, 73,74 \mathrm{~Sv}, 75 \mathrm{Pl}, 75 \mathrm{~Sv}, 77,78 \mathrm{Pl}, 78 \mathrm{~Sv}, 78 \mathrm{Zn}, 79,79 \mathrm{Pl}, 79 \mathrm{~Sv}, 79 \mathrm{Zn}, 80,80 \mathrm{Pl}, 80 \mathrm{~Sv}$, $80 \mathrm{Zn}, 83,83 \mathrm{PI}, 84,84 \mathrm{PI}, 84 \mathrm{Zn}, 87,87 \mathrm{PI}, 87 \mathrm{~Sv}, 87 \mathrm{Zn}, 88 \mathrm{PI}, 90,91 \mathrm{~Sv}, 92,92 \mathrm{~Sv}, 93,96 \mathrm{Zn}, 97,97 \mathrm{~Sv}, 97 \mathrm{Zn}$, $98 \mathrm{~S} v, 99 \mathrm{PI}, 99 \mathrm{Zn}, 102 \mathrm{PI}, 107,107 \mathrm{Pl}, 111,111 \mathrm{PI}, 112,112 \mathrm{PI}, 112 \mathrm{~Sv}, 114 \mathrm{~Sv}, 115,115 \mathrm{~Sv}, 115 \mathrm{Zn}, 116,116 \mathrm{Pl}$, $116 \mathrm{~Sv}, 116 \mathrm{Zn}, 117,117 \mathrm{PI}, 117 \mathrm{Zn}, 120,120 \mathrm{Pl}, 120 \mathrm{~Sv}, 120 \mathrm{Zn}, 121 \mathrm{~Sv}, 122,122 \mathrm{~Sv}, 124,124 \mathrm{Zn}, 125,125 \mathrm{~Sv}$, $126,126 \mathrm{Pl}, 127,127 \mathrm{Pl}, 127 \mathrm{~Sv}, 127 \mathrm{Zn}, 129,129 \mathrm{~Sv}, 131,132,132 \mathrm{Pl}, 132 \mathrm{~Sv}, 132 \mathrm{Zn}, 134,134 \mathrm{PI}, 134 \mathrm{~Sv}, 134 \mathrm{Zn}$, $135,135 \mathrm{Pl}, 135 \mathrm{~Sv}, 135 \mathrm{Zn}, 136,136 \mathrm{Pl}, 136 \mathrm{~Sv}, 136 \mathrm{Zn}, 138 \mathrm{Pl}, 139,139 \mathrm{Pl}, 139 \mathrm{~Sv}, 139 \mathrm{Zn}, 140,140 \mathrm{Pl}, 140 \mathrm{~Sv}$, $140 \mathrm{Zn}, 141 \mathrm{Zn}, 143 \mathrm{Pl}, 143 \mathrm{~Sv}, 145,146,146 \mathrm{PI}, 146 \mathrm{Zn}, 147,149,149 \mathrm{PI}, 150,150 \mathrm{PI}, 150 \mathrm{~Sv}, 150 \mathrm{Zn}, 151,153$, $153 \mathrm{PI}, 153 \mathrm{Zn}, 155 \mathrm{Zn}, 156 \mathrm{PI}, 157 \mathrm{Zn}, 159 \mathrm{PI}, 162 \mathrm{PI}$.

In cultivated soils of the Western Pomerania, Gl. dominikii ranked fifth among the most frequently occurring fungi and was one of the eudominants. Of the ten 
plant species considered, this fungus was not found to occur among roots of $\mathrm{Br}$. oleracea and $F$. vesca.

General distribution. According to Bła szkowski (1993a), Gl dominikii occurs in the whole Poland. However, the occurrence of this fungus is irregular and it seems to prefer cultivated sites. Jansa et al. (2002) suggested that sporulation of some species of AMF of cultivated soils activates agrochemical practices. Apart from Poland, this fungus has also been found in cultivated soils of Germany and Great Britain (Walker, pers, inf.).

\section{Glomus etunicatum Becker et Gerd.}

$\mathrm{n}=0 ; \mathrm{nPl}=2 ; \mathrm{nSv}=1 ; \mathrm{nZn}=1: 5 \mathrm{Pl}, 22 \mathrm{Pl}, 39 \mathrm{Zn}, 127 \mathrm{~Sv}$.

The presence of Gl. etunicatum in cultivated soils of the Western Pomerania indicated only four trap cultures representing $B r$. oleracea, Be. vulgaris, T. aestivum, and $Z$. mays.

General distribution. Glomus etunicatum has originally been described based on spores isolated from the root zone of Andropogon scoparius Michx. and Z. mays cultivated in Illinois (Becker and Gerdemann 1977). Later, this fungus has been encountered in agricultural soils of Florida (Medina et al. 1988), California (Nemec et al. 1981), Kansas, Wisconsin, and Minnesota (Hetrick and Bloom 1983; Koske and Tews 1987; Pfleger and Steward 1989), as well as in orchards with Malus domestica Borkh. located in 18 states of the USA (Mille r et al. 1985).

Remarks. According to Btaszkowski (1993a), Gl. etunicatum probably commonly occurs in different regions of Poland and is adapted to a wide range of plant hosts and soil conditions,

Glomus fasciculatum (Thaxter) Gerd. et Trappe emend. Walker et Koske

$\mathrm{n}=6 ; \mathrm{nPl}=3 ; \mathrm{nSv}=4 ; \mathrm{nZn}=4: 2,3 \mathrm{~Sv}, 4 \mathrm{Pl}, 11,12 \mathrm{Zn}, 25 \mathrm{~Sv}, 29,52,63 \mathrm{~Sv}, 74,86,91 \mathrm{~Sv}, 93 \mathrm{Zn}, 98 \mathrm{Zn}, 111 \mathrm{Pl}$, $148 \mathrm{Zn}, 149 \mathrm{Pl}$.

Glomus fasciculatum was found in 17 of the 162 soil and root samples of 6 of the 10 plant species considered in this study. Spores of this fungus occurred in samples coming from both the field and trap cultures with all the plant hosts used.

General distribution. Glomus fasciculatum has for the first time been found on sphagnum moss in Canada (Thaxter 1922). Among roots of cultivated plants, the fungus has been found in, c. g., California and Florida (Menge et al. 1978; Schenck and Smith 1981), Germany (Land and Schönbeck 1991), India (Selvaraj and Subramanian 1979), Taiwan (Wu and Chen 1986), New Zealand (Crush 1973), and Australia (Hayman and Stovold 1979).

In Błaszkowski's (1993a) studies, Gl. fasciculatum was the sixth species in respect of the frequency of occurrence and the third among the eudominants of AMF of cultivated soils of Poland. 
Glomus fuegianum (Spegazzini) Trappe et Gerd.

$\mathrm{n}=1 ; \mathrm{nPl}=0 ; \mathrm{nSv}=0 ; \mathrm{nZn=0:39.}$

In studies of the authors of this study, Gl. fuegianum was recovered only from under Be. vulgaris cultivated in Stare Czarnowo.

General distribution. Glomus fuegianum has originally been discovered in $\mathrm{Ar}$ gentina (Thaxter 1922). There is no other literature report of the occurrence of this fungal species in cultivated soils.

Błaszkowski (1998a, 2003) found Gl. fuegianum in three soil and root samples collected under Juniperus communis L. growing in inland dunes of the Kampinos National Park.

Glomus geosporum (Nicol. et Gerd.) Walker

$\mathrm{n}=3 ; \mathrm{nPl}=5 ; \mathrm{nSv}=5 ; \mathrm{nZn}=7: 7 \mathrm{Zn}, 9 \mathrm{Pl}, 16 \mathrm{PI}, 16 \mathrm{Zn}, 17 \mathrm{~Sv}, 20 \mathrm{Zn}, 22,23 \mathrm{~Sv}, 31 \mathrm{Zn}, 32 \mathrm{~Sv}, 33 \mathrm{Pl}, 38,39 \mathrm{Pl}, 40 \mathrm{~Sv}$. $50,55 \mathrm{Zn}, 59 \mathrm{PI}, 61 \mathrm{Zn}, 65 \mathrm{~Sv}, 104 \mathrm{Zn}$.

Glomus geosporum was found in 20 cultivated sites of the Western Pomerania. Of the ten plant species considered, this fungus was not revealed to occur in the root zone of $A$. sativa, $H$. vulgare, and $S$. cereale.

General distribution. Glomus geosporum has originally been described based on spores recovered from the rhizosphere soil of $H$. vulgare cultivated in Scotland (Nicolson and Gerdemann 1968). Later, it has been found among roots of, e. g., Festuca spp. cultivated in the western states of the USA and Canada (Molina and Trappe 1978), in cultivated soils of Florida (Schenck and Sm ith 1981), and orchards with $M$. domestica located in 18 states of the USA (Miller et al. 1985).

Błaszkowski (1993a) found Gl. geosporum to be the fifth species in respect of the frequency of occurrence and the third one among the dominating AMF in cultivated soils of Poland.

\section{Glomus intraradices Schenck et Smith}

$\mathrm{n}=0 ; \mathrm{nPI}=0 ; \mathrm{nSv}=1 ; \mathrm{nZn}=1 ; 9 \mathrm{~Sv}, 85 \mathrm{Zn}$.

In the studies presented here, spores of $G l$. intraradices were isolated from only two trap cultures representing $A$. sativa and $F$. vesca cultivated in Witnica and Kołbacz, respectively.

General distribution. Glomus intraradices has been described from spores isolated from under $P$. notatum cultivated in Florida (Schenck and $\mathrm{Sm}$ it h 1982), where it has been one of the arbuscular fungi most frequently found in agricultural sites (Schenck and $\mathrm{Sm}$ ith 1981, 1982). This fungus has also been recorded in cultivated soils of Kentucky (An et al. 1983), Finland (Williams et al. 1992), France (Gianinazzi-Pearson et al. 1985), and Germany (Land and Schönbeck 1991).

Glomus intraradices was not so far reported from cultivated soils of Poland. Using methods of molecular biology, Turnau et al. (2001) revealed Gl. intraradices in roots of $F$. vesca growing in a highly $\mathrm{Zn}$-contaminated heaps located near Chrzanów. 
Glomus laccatum Błaszk.

$\mathrm{n}=0 ; \mathrm{nPl}=4 ; \mathrm{nSv}=4 ; \mathrm{nZn}=10: 19 \mathrm{~Sv}, 20 \mathrm{Zn}, 31 \mathrm{Zn}, 33 \mathrm{Zn}, 34 \mathrm{PI}, 39 \mathrm{Zn}, 40 \mathrm{~Sv}, 46 \mathrm{~Sv}, 46 \mathrm{Zn}, 48 \mathrm{Zn}, 52 \mathrm{n}, 53 \mathrm{Pl}$, $53 \mathrm{Zn}, 54 \mathrm{~Sv}, 129 \mathrm{Zn}, 131 \mathrm{PI}, 136 \mathrm{PL}, 146 \mathrm{~Sv}$.

In the Western Pomerania, Gl. laccatum was revealed only in 18 trap cultures representing six plant species cultivated in nine localities.

General distribution. No literature data exists of the occurrence of Gl. laccatum in cultivated soils. However, the results of both this study and those of trap cultures containing soils of different uncultivated areas (Tadych and B laszkowski 2000; Blaszkowski 2003) indicated that Gl. laccatum is rather a frequently occurring arbuscular fungus in Poland.

Remarks. Glomus laccanum produces small and colourless spores with a delicate wall. Hence, the infrequent finding of this species in soil samples collected from the field probably resulted from the same reasons making difficulties to reveal, e. $\mathrm{g}$, Arch trappei (see above).

Glomus macrocarpum Tul. et Tul.

$\mathrm{n}=8 ; \mathrm{nPl}=0 ; \mathrm{nSv}=0 ; \mathrm{nZn}=0: 9,41,71,115,125,133,143,155$.

In the studies discussed here, spores of Gl. macrocarpum were found in eight soil and root samples coming only from the field. The species occurred among roots of 6 of the 10 plant species investigated.

General distribution. Glomus macrocarpum has for the fist time been found in the East of the North America (Thaxter 1922). In cultivated sites, this fungus has been recorded in, e. g., many states of the USA (Hetrick and Bloom 1983; Nemec et al. 1981; Molina et al. 1978; Pfleger and Steward 1989), Grad Britain (Godfrey 1957), and Australia (Hall and Abbott 1984).

Błaszkowski $(1993 \mathrm{a}, \mathrm{b})$ found spores of this fungus in 43 of the 173 rhizosphere soil samples of cultivated plants of Poland examined.

Remarks. There is no literature report of sporulation of $G l$ macrocarpum in pot cultures.

Glomus microcarpum Tul. et Tul.

$\mathrm{n}=1 ; \mathrm{nP} \mid=0 ; \mathrm{nSv}=0 ; \mathrm{nZn}=0 ; 140$.

Sporocarps with spores of Gl. microcarpum were recovered only from under $T$. aestivum cultivated in Kanin.

General distribution. Glomus microcarpum has been described using specimens collected near Paris (Tulasne and Tulasne 1845). In cultivated sites, this fungus was present in, e. g., California (Nemec et al. 1981), Wyoming (Stahl and Christensen 1982), Kansas (Hetrick and Bloom 1983), Kentucky (An et al. 1993), Canada (Molina et al. 1978), and Australia (Hayman and Stovold 1979).

Błaszkowski (1993a, b) found Gl. microcarpum to occur in 11 of the 173 samples of cultivated soils examined. 


\section{Glomus mosseae (Nicol. et Gerd.) Gerd. et Trappe}

$\mathrm{n}=61 ; \mathrm{nPl}=88 ; \mathrm{nSv}=98 ; \mathrm{nZn}=108 ; 1,1 \mathrm{Pl}, 1 \mathrm{~Sv}, 1 \mathrm{Zn}, 2 \mathrm{Pl}, 2 \mathrm{Zn}, 3,3 \mathrm{Pl}, 3 \mathrm{Zn}, 4 \mathrm{~Sv}, 5 \mathrm{~Sv}, 5 \mathrm{Zn}, 6 \mathrm{Pl}, 6 \mathrm{~Sv}, 6 \mathrm{Zn}$, $7 \mathrm{Pl}, 8 \mathrm{Pl}, 8 \mathrm{Zn}, 9 \mathrm{PI}, 9 \mathrm{~Sv}, 10 \mathrm{Zn}, 11 \mathrm{~Sv}, 12 \mathrm{~Sv}, 13,13 \mathrm{Pl}, 13 \mathrm{Zn}, 14 \mathrm{Pl}, 14 \mathrm{~Sv}, 14 \mathrm{Zn}, 15 \mathrm{Pl}, 15 \mathrm{~Sv}, 15 \mathrm{Zn}, 16 \mathrm{Pl}, 16 \mathrm{~Sv}$, $16 \mathrm{Zn}, 17 \mathrm{Pl}, 17 \mathrm{~Sv}, 18 \mathrm{Pl}, 18 \mathrm{~Sv}, 18 \mathrm{Zn}, 19,19 \mathrm{Pl}, 20,20 \mathrm{Pl}, 20 \mathrm{~Sv}, 20 \mathrm{Zn}, 21,21 \mathrm{Pl}, 2 \mathrm{LSv}, 21 \mathrm{Zn}, 22,22 \mathrm{~Sv}, 22 \mathrm{Zn}, 23$, $23 \mathrm{Pl}, 23 \mathrm{~Sv}, 23 \mathrm{Zn}, 24,24 \mathrm{Pl}, 24 \mathrm{~Sv}, 24 \mathrm{Zn}, 26,27 \mathrm{Pl}, 27 \mathrm{~Sv}, 28,28 \mathrm{Pl}, 28 \mathrm{~Sv}, 28 \mathrm{Zn}, 29,29 \mathrm{Pl}, 29 \mathrm{Zn}, 30,30 \mathrm{Pl}, 3 \mathrm{CSv}$, $30 \mathrm{Zn}, 31 \mathrm{Pl}, 32 \mathrm{Pl}, 34 \mathrm{Pl}, 34 \mathrm{~Sv}, 35 \mathrm{Zn}, 36 \mathrm{~Sv}, 36 \mathrm{Zn}, 37 \mathrm{~Sv}, 37 \mathrm{Zn}, 385 \mathrm{v}, 38 \mathrm{Zn}, 39 \mathrm{Zn}, 40 \mathrm{Pl}, 40 \mathrm{~Sv}, 40 \mathrm{Zn}, 41,41 \mathrm{Pl}$, $41 \mathrm{~Sv}, 41 \mathrm{Zn}, 42 \mathrm{~Sv}, 43 \mathrm{Pl}, 43 \mathrm{~Sv}, 44 \mathrm{Pl}, 44 \mathrm{~Sv}, 45 \mathrm{PI}, 45 \mathrm{~Sv}, 45 \mathrm{Zn}, 46,46 \mathrm{Pl}, 46 \mathrm{Zn}, 47,47 \mathrm{Zn}, 48,48 \mathrm{Pl}, 48 \mathrm{~Sv}, 48 \mathrm{Zn}$, $49 \mathrm{~Sv}, 50 \mathrm{Pl}, 50 \mathrm{~Sv}, 51 \mathrm{~Sv}, 52 \mathrm{Pl}, 52 \mathrm{~Sv}, 52 \mathrm{Zn}, 54 \mathrm{PI}, 54 \mathrm{~Sv}, 54 \mathrm{Zn}, 55 \mathrm{Pl}, 55 \mathrm{~Sv}, 56 \mathrm{Pl}, 56 \mathrm{~Sv}, 56 \mathrm{Zn}, 57 \mathrm{~Sv}, 57 \mathrm{Zn}, 58 \mathrm{Pl}$, $59 \mathrm{~Sv}, 60,60 \mathrm{Pl}, 60 \mathrm{~Sv}, 61,61 \mathrm{~Sv}, 63 \mathrm{Zn}, 64,64 \mathrm{Zn}, 65 \mathrm{Zn}, 66 \mathrm{Pl}, 66 \mathrm{~Sv}, 66 \mathrm{Zn}, 67,68,68 \mathrm{~Sv}, 68 \mathrm{Zn}, 69,70,70 \mathrm{Pl}$, $70 \mathrm{Zn}, 73,73 \mathrm{Pl}, 73 \mathrm{Zn}, 74 \mathrm{Pl}, 75,75 \mathrm{Zn}, 76,76 \mathrm{Pl}, 77,77 \mathrm{~Sv}, 78,78 \mathrm{Zn}, 79,79 \mathrm{~Sv}, 79 \mathrm{Zn}, 81 \mathrm{Zn}, 83,83 \mathrm{~Sv}, 83 \mathrm{Zn}$, $85 \mathrm{Zn}, 88,89 \mathrm{Zn}, 90,90 \mathrm{~Sv}, 90 \mathrm{Zn}, 91,91 \mathrm{~Sv}, 91 \mathrm{Zn}, 92 \mathrm{~Sv}, 93,93 \mathrm{~Sv}, 94 \mathrm{~Sv}, 95,95 \mathrm{Zn}, 96 \mathrm{Pl}, 96 \mathrm{Zn}, 97,97 \mathrm{Zn}, 98$, $99 \mathrm{Pl}, 100 \mathrm{Zn}, 101,101 \mathrm{Zn}, 102,102 \mathrm{~Sv}, 103,104 \mathrm{~Sv}, 104 \mathrm{Zn}, 105,105 \mathrm{~Sv}, 105 \mathrm{Zn}, 106,106 \mathrm{Pl}, 106 \mathrm{~Sv}, 106 \mathrm{Zn}$, $107 \mathrm{Pl}, 107 \mathrm{Zn}, 108 \mathrm{Pl}, 108 \mathrm{~Sv}, 108 \mathrm{Zn}, 109 \mathrm{~Sv}, 109 \mathrm{Zn}, 110,110 \mathrm{Zn}, 111 \mathrm{~Sv}, 111 \mathrm{Zn}, 112 \mathrm{Pl}, 112 \mathrm{Zn}, 113,113 \mathrm{Pl}$, $113 \mathrm{~Sv}, 113 \mathrm{Zn}, 114,114 \mathrm{PI}, 114 \mathrm{~Sv}, 114 \mathrm{Zn}, 115 \mathrm{PI}, 115 \mathrm{Zn}, 116 \mathrm{PI}, 116 \mathrm{~Sv}, 117,117 \mathrm{PI}, 117 \mathrm{~Sv}, 117 \mathrm{Zn}, 118 \mathrm{Pl}$, $118 \mathrm{Zn}, 119 \mathrm{PI}, 119 \mathrm{~Sv}, 119 \mathrm{Zn}, 120,120 \mathrm{Pl}, 120 \mathrm{~Sv}, 120 \mathrm{Zn}, 121,121 \mathrm{PI}, 121 \mathrm{~Sv}, 121 \mathrm{Zn}, 122,122 \mathrm{~Sv}, 122 \mathrm{Zn}, 123$, $123 \mathrm{~Sv}, 123 \mathrm{Zn}, 124 \mathrm{Pl}, 124 \mathrm{~Sv}, 124 \mathrm{Zn}, 125 \mathrm{PL}, 125 \mathrm{Zn}, 126,126 \mathrm{Pl}, 126 \mathrm{Zn}, 127 \mathrm{Pl}, 127 \mathrm{~Sv}, 127 \mathrm{Zn}, 128,128 \mathrm{Pl}$, $128 \mathrm{~Sv}, 128 \mathrm{Zn}, 129,130 \mathrm{Pl}, 130 \mathrm{~Sv}, 130 \mathrm{Zn}, 131 \mathrm{Pl}, 131 \mathrm{~Sv}, 131 \mathrm{Zn}, 132 \mathrm{Pl}, 132 \mathrm{~Sv}, 132 \mathrm{Zn}, 133 \mathrm{Pl}, 134 \mathrm{Pl}, 134 \mathrm{~Sv}$, $134 \mathrm{Zn}, 135 \mathrm{Pl}, 135 \mathrm{~Sv}, 135 \mathrm{Zn}, 136 \mathrm{~Sv}, 137 \mathrm{~Sv}, 137 \mathrm{Zn}, 138 \mathrm{PI}, 138 \mathrm{~Sv}, 138 \mathrm{Zn}, 139 \mathrm{PI}, 139 \mathrm{~Sv}, 139 \mathrm{Zn}, 140,140 \mathrm{~Sv}$, $141 \mathrm{Pl}, 141 \mathrm{Zn}, 142 \mathrm{Pl}, 142 \mathrm{~Sv}, 143 \mathrm{Pl}, 143 \mathrm{~Sv}, 143 \mathrm{Zn}, 144,144 \mathrm{~Sv}, 144 \mathrm{Zn}, 145,145 \mathrm{Pl}, 145 \mathrm{~Sv}, 145 \mathrm{Zn}, 146 \mathrm{Pl}$, $146 \mathrm{~Sv}, 146 \mathrm{Zn}, 147 \mathrm{PI}, 147 \mathrm{~Sv}, 147 \mathrm{Zn}, 148,148 \mathrm{Pl}, 148 \mathrm{~Sv}, 148 \mathrm{Zn}, 149,149 \mathrm{Zn}, 150 \mathrm{Pl}, 150 \mathrm{~Sv}, 150 \mathrm{Zn}, 151 \mathrm{~Sv}$, $151 \mathrm{Zn}, 152 \mathrm{PI}, 152 \mathrm{~Sv}, 152 \mathrm{Zn}, 153 \mathrm{Pl}, 153 \mathrm{~Sv}, 153 \mathrm{Zn}, 154 \mathrm{Pl}, 154 \mathrm{Zn}, 155 \mathrm{Zn}, 156 \mathrm{~Sv}, 156 \mathrm{Zn}, 158 \mathrm{Pl}, 158 \mathrm{~Sv}$, $158 \mathrm{Zn}, 159,159 \mathrm{Pl}, 159 \mathrm{~Sv}, 159 \mathrm{Zn}, 160 \mathrm{Pl}, 160 \mathrm{~Sv}, 160 \mathrm{Zn}, 161,161 \mathrm{Pl}, 161 \mathrm{~Sv}, 161 \mathrm{Zn}, 162 \mathrm{Pl}, 162 \mathrm{~Sv}, 162 \mathrm{Zn}$.

In the cultivated soils of the Western Pomerania, Gl. masseae ranked second in respect of the frequency of occurrence and one of the dominants among the species of AMF revealed. It accompanied all the cultivated plant species compared.

General distribution. The holotype of Gl. mosseae comes from under T. aestivum cultivated in Scotland (Nicolson and Gerdemann 1968). Glomus mosseae is one of the species of AMF most frequently listed in the literature. In cultivated sites, spores of this fungus have been found in, e. g., many states of the USA (A n et al. 1993; Nemec et al. 1981; Schenck and Smith 1981; Stahl and Christensen 1982; Hetrick and Bloom 1983; Miller et al. 1985), Canada (Hamel et al. 1994; Talukdar and Germida 1993), France (Gianinazzi-Pearson et al. 1985), Germany (Land and Schönbeck 1991), Finland (Vestberg 1995), India (Sulochama and Monoharachary 1989), and Australia (Hayman and Stovold 1979).

Błaszkowski's (1993a) studies showed that Gl. mosseae was the species most frequently occurring and the second among the eudominants in cultivated sites of Poland.

Glomus spurcum Pfeiffer et al. emend. Kennedy et al.

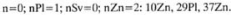

Only three trap cultures representing $B e$. vulgare and $T$. aestivum revealed $G L$. spurcum in three cultivated sites of the Western Pomerania.

General distribution. Glomus spurcum has originally been described from spores isolated from a greenhouse bed of sand used for propagation of various ornamental plants cultivated in Arizona (Pfeiffer et al. 1996).

The only literature report of the presence of GL spurcum among roots of agricultural plants is that of Błaszkowski et al. (2003). 
Glomus verruculosum Błaszk.

$\mathrm{n}=0 ; \mathrm{nPl}=0 ; \mathrm{nSv}=0 ; \mathrm{nZn}=1: 3 \mathrm{Zn}$.

Spores of Gl. verniculosum were revealed only in one trap culture containing a mixture of rhizosphere soil and roots of Be. vulgare cultivated in Stare Czarnowo.

General distribution. Glomus verruculosum has been described based on spores isolated from under Glyceria aquatica (L.) Wahlb. growing at the sandy bank of the Odra river in Szczecin (Błaszkowski and Tadych 1997).

This paper is the first report of the occurrence of $G l$. vernuculosum in a cultivated site.

\section{Paraglomus occultum Walker}

$\mathrm{n}=0 ; \mathrm{nPl}=1 ; \mathrm{nSv}=2 ; \mathrm{nZn1}: 28 \mathrm{~Sv}, 32 \mathrm{Zn}, 48 \mathrm{~Sv}, 146 \mathrm{Pl}$.

The presence of $P$. occultum in cultivated soils of the Western Pomerania confirmed only four trap cultures with soil and root mixtures taken from under $\mathrm{Be}$. vulgare, $T$, aestivum, and Z. mays.

General distribution. The holotype of $P$. occultum comes from spore populations recovered from the rhizosphere soils of Populus spp, and associated grasses growing in a nursery in Iowa, USA (Walker 1982). Subsequently, the fungus has sporadically been revealed among roots of $M$. domestica cultivated in 18 states of the USA (Mille r et al. 1985), as well as Glyci. max and $Z$. mays produced in Pennsylvania (Douds et al. 1993).

Błaszkowski (1993a) isolated spores of $P$ occultum from 10 samples of cultivated soils of Poland.

\section{Scutellospora dipurpurescens Morton et Koske}

$\mathrm{n}=15 ; \mathrm{nPl}=7 ; \mathrm{nSv}=7 ; \mathrm{nZn}=1: 14 \mathrm{~Sv}, 19,30,32,56 \mathrm{Pl}, 63,68,71,71 \mathrm{PI}, 71 \mathrm{Zn}, 76 \mathrm{~Sv}, 79,80,80 \mathrm{PI}, 805 \mathrm{v}, 88$. $102 \mathrm{~Sv}, 107,113,119,122 \mathrm{PL}, 124 \mathrm{PI}, 130 \mathrm{~Sv}, 136,141 \mathrm{PI}, 143,143 \mathrm{~Sv}, 150 \mathrm{~Sv}, 158,159 \mathrm{Pl}$

Scutellospora dipurpurescens was revealed in 30 sites, in which six plant species were cultivated. This fungus markedly more frequently sporulated in the field conditions than in trap cultures. The lack of or low sporulation of Scu. dipurpuresens in trap cultures probably resulted from (1) the exclusion or suppression of the fungus by species more competitive or faster adapting to the conditions of trap cultures and (2) the incompatability of the under- and above-ground conditions, as well as the plant hosts of these cultures with the ecological requirements of the fungus ( $\mathrm{Br}$ un drett et al. 1999a, b; Jansa et al. 2002).

General distribution. The type of Scu. dipurpurescens comes from a natural site of West Virginia, where it has also been revealed in cultivated soils (Morton and Koske 1988).

According to Błaszkowski (1993a, 1994a), Scu. dipurpurescens is widely distributed in Poland, although it prefers uncultivated sites. This fungus is the most frequently occurring member of the genus Scutellospora in Poland.

Remarks. Despite the lack of literature reports, Scu. dipurpurescens probably is widely distributed in the world. A large part of reports of the finding of Scu. calospora (Nicol. et Gerd.) Walker et Sanders probably regards Scu. dipurpurescens. 
The two species are indistinguishable under a dissecting microscope and difficult to recognize when examined under a compound microscope.

\section{Scutellospora pellucida (Nicol. et Schenck) Walker et Sanders}

$\mathrm{n}=2 ; \mathrm{nPl}=0 ; \mathrm{nSv}=0 ; \mathrm{nZn}=0: 76,79$.

In the studies presented here, spores of Scu. pellucida occurred only in two fieldcollected samples collected under $S$. cereale and T. aestivum cultivated in Kierzkowo and Derczewo, respectively.

General distribution. Scutellospora pellucida has originally been described from spores recovered from under Glyci. max grown in Florida (Nicolson and Schenck 1979), where the fungus has also been found among roots of other cultivated plant species (Schenck and Kinloch 1980). Additionally, Scu. pellucida has been encountered in the root zone of $T$. aestivum cultivated in Kansas (Hetrick and Bloom 1983), sporadically under $M$. domestica growing in orchards of 18 states of the USA (Miller et al. 1985), in many cultivated sites of the Central and South America (Sieverding 1989), and in Japan (Saito and Vargas 1991).

In Poland, Błaszkowski (1993a) found Scu. pellucida in five cultivated sites.

\section{REFERENCES}

A b bott L. K. 1982. Comparative anatomy of vesicular-arbuscular myeorrhizas formed on subterranean clover. Aust. J. Bot. 30: 485-499.

Ames R. N., Linderman R. G. 1976. Aceulospora trappoi sp. nov. Mycotaxon 3: 565-569.

Ames R. N., Schneider R. W. 1979. Entrophospora, a new genus in the Endogonaceae. Mycotaxon 8: $347-352$.

An Z. Q., Hendrix J. W. Hershman D. E., Ferriss R. S., Henson G. T. 1993. The influence of crop rotation and soil furnigation on a mycorrhizal fungal community associated with soybean. Mycorrhiza 3:171-182.

Becker W. N. Gerdeman I. W. 1977. Glomus etunicatus sp. nov, Mycotaxon 6: 29-32.

Błaszkowski J. 1988. Four new species of the Endogonacene (Zygomycotina) from Poland. Karstenia 27: $37-42$

Braszkowski J. 1991. Polish Endogonaceae 9. Glomus aggngatum with spores forming an evanescent outermost wall. Crypt. Bot. 2/3: 130-135.

Błaszkowski J. 1993a. Comparative studies of the occurrence of arbuscular fungi and mycorrhizac (Glomales) in cultivated and uncultivated soils of Poland. Acta Mycol. 28: 93-140.

Błaszkowski J. 1993b. Polish Glomales 12. Glonus macrocarpum Tul. et Tul, and Glomus microcarpum Tul. et Tul. Bull. Pol. Ac. Sci. Biol. 41: 29-39.

Błaszkowski J. 1994. Polish Glomales 10. Acaulospora dilatata and Scutellospora dipurpurascens. Mycorrhiza 4: 173-182.

Btaszkowski J. 1994. Arbuscular fungi and mycorrhizac (Glomales) of the Hel Peninsula, Poland. Mycorrhiza 5: 71-88.

Błaszkowski J. 2003. Arbuscular mycorrhizal fungi (Glomeromycota), Endogane, and Complexipes spccies deposited in the Department of Plant Pathology, University of Agriculture in Szczecin, Poland. http://www.agro.ar.szezecin.pl/ - jblaszkowski/.

Btaszkowski J., Adamska I., Czerniawska B. 2003. Glomus clarotidetum and G. spurcum, arbuscular mycorrhizal fungi (Glomeromycota) new for Poland and Europe, respectively. Acta Soc. Bot. Pol. 72: 149-156.

Błaszkowski J., Tadych M. 1997. Glomus multifonm and G. vemuculosum, two new species in Glomales (Zygomyectes) from Poland. Mycologia 89: 804-811.

Błaszkowski J., Tadyeh M., Madej T. 2002. Arbuscular mycorrhizal fungi (Glomales, Zygomycota) of the Blędowska Desert. Acta Soc. Bot. Pol. 71: 71-85. 
Brundrett M. C., Abbott L. K., Jasper D. A. 1999. Glomalean mycorrhizal fungi from tropical Australia. 1. Comparison of the effectiveness and specificity of different isolation procedures. My. corrhiza 8: $305-314$.

Brundrett M. C., Jasper D. A., Ashwath N. 1999. Glomalean mycorrhizal fungi from tropical Australia. II. The effect of nutrient levels and host species on the isolation of fungi. Mycorrhiza 8: $315-321$.

Crush J. R. 1973. Significance of endomycorrhizae in tussock grassland in Ontago, New Zeland. N. Z. J. Bot. 11: $645-660$.

Dalpé Y., Granger R. L, Furlan V. 1986. Abondance relative et diversite des Endogonaces dans un sol de verger du Quebec. Can. J. Bot. 64: 912-917.

Douds D. D., Janke R. R., Petcrs S. E. 1993. VAM fungus spore populations and colonization of roots of maize and soybean under conventional and low-input sustainable agriculture. Agric. Ecosyst. Environm. 43:325-335.

Gemm a J. N., Koske R. E., Carreiro M. 1989. Seasonal dynamics of selected species of VA mycorthizal fungi in a sand dune. Mycol. Res. 92: 317-321.

Gerdemann J. W., Trappe J. M. 1974. The Endogonaceac in the Pacific Northwest. Myc. Memoir. $5: 1 \cdot 76$.

Gianinazzi-Pearson V., Gianinazzi S., Trouvelot A. 1985. Evaluation of the infectivity and effectiveness of indigenous vesicular-arbuscular fungal populations in some agricultural soil in Burgundy. Can. J. Bot. 63: 1521-1524.

Godfrey R. M. 1957. Studies of British species of Endogone. I. Morphology and taxonomy. Trans. Br. Mycol. Soc, 40: 117-135.

Hall I. R. 1975. Endonycorrhizas of Metrosideros tumbellata and Weinmanta racemosa. N. Z. J. Bot. 13: $463-472$.

Hall I. R. 1977. Species and mycorrhizal infections of New Zeland Endogonaceae. Trans. Br. Mycol. Soc. $68: 341-356$.

Hall I. R, A bbott L. K. 1984. Some Endogonaceae from south western Australia. Trans. Br. Mycol. Soc. 83: 203-208.

Hamel C, Dalpé Y, Lapierre C, Simard R. R., Smith D. L. 1994. Composition of the vesiculararbuscular mycorrhizal fungi population in an old meadow as affected by $\mathrm{pH}$, phosphorous and soil disturbance. Agric. Ecosyst. Environm. 49: 223-231.

H a as J. H., Men ge J. A. 1990. VA-mycorrhizal fungi and soil characteristies in avocado (Persea americana Mill.) orchard soils, Plant and Soil 127: 207-212.

Haym an D. S., Stovold C. E. 1979. Spore populations and infectivity of vesicular-arbuscular mycorrhizal fungi in New South Wales, Aust. J. Bot. 27: 227-233.

Hetrick D. B., A., Bloom 1. 1983. Vesicular-arbuscular mycorrhizal fungi associated with native tall grass praire and cultivated winter wheat. Can. J. Bot. 61:2140-2146.

1waniuk A., Błaszkowski J. 2004. Arbuscular mycorrhizal fungi and arbuscular mycorrhizac (Glomeromycota) of agricultural soils of the Western Pomerania. Part I. Occurrence of arbuscular mycorrhizal fungi and arbuscular mycorrhizac. Acta Mycol. 39 (1):65-91.

Jansa J., Mozafar A., Anken T, Ruh R, Sanders 1. R., Frossard E, 2002. Diversity and structure of AMF communities as affected by tillage in a temperate soil. Mycorrhiza 12: 225-234.

Koske R. E. 1985. Glomus aggregalum emended: A distinct taxon in the Glomus fasciculatum complex. Mycologia 77: 619-630.

Koske R. E., Halvorson W. L. 1981. Ecological studies of vesicular-arbuscular mycorrhizae in a barrier sand dune. Can. J. Bot. 59: 1413-1422.

Koske R. E., T ews L. L 1987. Vesicular-arbuscular mycorrhizal fungi of Wisconsin sandy soils. My. cologia 79: 901-905.

Koske R. E., Gemma J. N, Jackson N. 1997. Mycorrhizal fungi associated with three species of turfgrass, Can. J. Bot. 75: 320-332.

Land S., Schö n beck F. 1991. Influence of different soil types on abundance and seasonal dynamics of vesicular arbuscular mycorrhizal fungi in arable soils of North Germany. Mycorthiza 1:39-44.

Lee P. J., Koske R. E. 1994. Gigaspora gigantea: parasitism of spores by fungi and actinomycetes. Mycol. Res. 98: $458-466$.

Medin a O. A., Kretschmer A. E., Sylvia D. M. 1988. The occurrence of vesicular-arbuscular mycorrhizal fungi on tropical forage legumes in south Florida. Tropical Grasslands 22: 74-78. 
Menge J. A., Johnson E. L. V., Platt R. C. 1978. Mycorrhizal dependency of several citrus cultivars under three nutrient regimes. New Phytol. 81: 553-559.

Miller D. D., Domoto P. A., Walker C. 1985. Mycorrhizal fungi at eighteen apple rostock plantings in the United States. New Phytol. 100: 379-391.

Molina R. J., Trappe J. M., Strickler G. S. 1978. Mycorrhizal fungi associated with Festuca in the western United States and Canada. Can. J. Bot. 56: 1691-1695.

Mort on J. B., Koske R. E. 1988. Scutellispora dipurpurescens, a new species in the Endogonaceae from West Wirginia. Mycologia 80: 520-524.

Morton J. B., Redecker D. 2001. Two families of Glomales, Archaeosporaceae and Paraglomaceae, with two new genera Archaeospora and Paraglomus, based on concordant molecular and morphological characters. Mycologia 93: 181-195.

Nemec S., Menge J. A., Platt R. G., Johnson E. L. V. 1981. Vesicular-arbuscular mycorrhizal fungi associated with citrus in Florida and California and notes on their distributions and ecology. Mycologia 73: 112-127.

Nicolson T. H., Gerdeman n J. W. 1968. Mycorhizal Endogone species. Mycologia 60: 313-325.

Nicolson T. H., S chen ck N. C. 1979. Endogonaceous mycorrhizal endophytes in Florida. Mycologia 71: $178-198$.

Pfeiffer C. M., Walker C, Bloss H. E, 1996. Glomus spurcum: a new endomycorrhizal fungus from Arizona. Mycotaxon 59: 373-382.

Pfleger F. L. Stcward E. L. 1989. Survey of the Endogonaceac in Minnesota with synoptic keys to genera and species. J. Minnesota Ac. Sci. 54: 25-29.

S aito M. Vargas R. 1991. Vesicular-arbuscular myeorrhizal fungi in some humus-rich Ando soils of Japan. Soil Microorg. 38: 3-15.

Sehenck N. C., Kinloch R. A. 1980. Incidence of mycorrhizal fungi on six field crops in monoculture on a newly cleared woodland site. Myeologia 72: 445-456.

Sehenck N. C., S mith G. S. 1981. Distribution and occurrence of vesicular-arbuscular mycorrhizal fungi on Florida agricultural crops, Soil Crop Sci. Soc, Florida, Proc, 40: 171-175.

Schen ck N. C, S mith G. S. 1982. Additional new and unreported species of mycorrhizal fungi (Endogonaceae) from Florida. Mycologia 74: 77-92.

Schenck N. C., S pain J. L. Howeler R. H. 1984. Several new and unreported vesicular-arbuscular mycorrhizal fungi (Endogonaceac) from Colombia. Mycologia 76: 685-699.

Schultz P. A., Bever J. D., Morton J. B. 1999. Acaulospora colossica sp. nov. from an old field in North Carolina and morphological comparisons with similar species, A. laevis and A. koskei. Mycologia 91: 676-683.

SchüBler A. S chwarzott D., Walker C. 2001. A new fungal phylum, the Glomeromycota: phylogeny and evolution. Myc. Res. 105: 1413-1421.

Selvaraj T, Subramanian G. 1987. Vesicular-arbuscular mycorrhizal fungi in roots and scale-like leaves of Acoras calamus Linn. and Calacasia esculenta Linn. Cur. Sci. 56; 1112-1114.

Sieverding E. 1989. Ecology of VAM fungi in tropical agrosystems. Agric., Ecosyst. Environ. 29: 369-390 .

Stahl P. D., Christensen M. 1982. Mycorrhizal fungi associated with Bouteloua and Agropyron in Wyoming sagebrush-grasslands. Mycologia 74:877-885

Sulochama T., Monoharachary C. 1989. Vesicular-arbuscular mycorrhizal associations of castor and safflower. Cur. Sei. 58: 459-461.

Ta dyc h M., B lasz kow sk i J. 2000. Succession of arbuseular mycorrhizal fungi in a deflation hollow of the Stowifiski National Park, Poland. Acta Soc. Bot. Pol. 69: 223-236.

Ta l ukdar N. C., G erm ida J. J. 1993. Occurrence and isolation of vesicular-arbuscular mycorrhizae in cropped field soils of Saskatchewan, Canada. Can. J. Microbiol. 39: 567-575.

Thaxter R. 1922. A revision of the Endogonaceae. Proc. Am. Acad. Arts Sci. 57: 291-350.

Trappe J. W. 1977. Three new Endogonaceac: Glomus constrictus, Sclerocystis clavispora, and Acaulospora scrobiculata. Mycotaxon 6:359-366.

Trappe J. W., Bloss E., Menge J. 1984, Glomus deserticola sp. nov, Mycotaxon 20: 123-127.

Tulasne L. R., Tulasne C. 1845. Fungi nonnulli hypogaei, novi minus cogniti act. Giorn. Bot. Ital. $2: 35-63$. 
Turnau K., Ryszka P., Gianinazzi-Pearson V, Van Tuinen D. 2001. Identification of arbuscular mycorrhizal fungi in soils and roots of plants colonizing zinc wastes in southern Poland. Mycor. rhiza 10: 169-174.

Vestberg M. 1995. Occurrence of some Glomales in Finland. Mycorrhiza 5: 329-336.

Walke r C. 1982. Species in the Endogonaceae: a new species (Glomus occultum) and a new combination (Glomus geosponum). Mycotaxon 15: 49-16.

Walker C., Vestberg M. 1998. Synonymy amongst the arbuscular mycorrhizal fungi: Glomus claro. iefeum, G. maculosum, G. multisubsienum and $G$. fistulosum. Ann. Bot. 82: 601-624.

Williams S. C. K., Vestberg M. Uosukainen M., Dodd J. C., Jeffries P. 1992. Effects of fertilizers and arbuscular mycorrhizal fungi on post-vitro growth of micropropagated strawberry. Agronomie 12: 851-857.

Wu Ch., Chen Z. 1986. The Endogonaceae of Taiwan. 1. A preliminary investigation of Endogonaceac of bambo vegetation at Chi-Tou areas, Central Taiwan. Taiwania 31: 65-85.

Grzyby i mikoryzy arbuskularne gleb rolniczych

województwa zachodniopomorskiego

II. Rozmieszczenie grzybów arbuskularnych

\section{Streszczenie}

Niniejsza, druga czẹşć artykułu o arbuskularnych grzybach mikoryzowych z gromady Glomeromycota gleb rolniczych województwa zachodniopomorskicgo przedstawia rozmieszczenie 26 gatunków tych grzybów w zarówno stanowiskach uwzględnionych w niniejszym stu. dium, jak i glebach uprawnych innych regionów Polski i świata zbadanych wcześniej. Grzyby te wyizolowano $z$ mieszanin gleby ryzosferowej $i$ korzeni zebranych z pola oraz kultur pułapkowych założonych z cześci każdej próby polowej i obsianych trzema gatunkami roslin gospodarzy. Wśród scharakteryzowanych gatunków, 18 pochodzi z rodzaju Glomus, po jednym z rodzajów Archaeospora, Entrophospora i Paraglomus, oraz trzy i dwa z rodzajów odpowiednio Acaulospora i Scutellospora. 